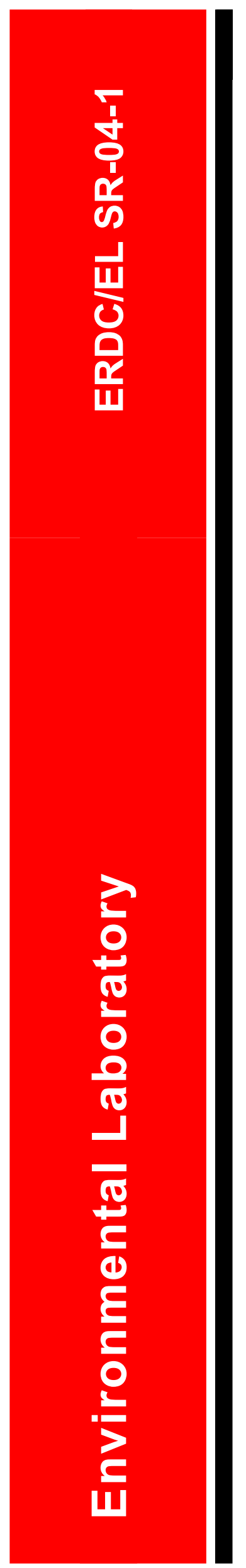

Water Operations Technical Support Program

\title{
SELECT Version 1.0 Beta: A One-Dimensional Reservoir Selective Withdrawal Model Spreadsheet
}

Michael L. Schneider, Steven C. Wilhelms,

February 2004

and Laurin I. Yates 


\section{SELECT Version 1.0 Beta: A One-Dimensional Reservoir Selective Withdrawal Model Spreadsheet}

Michael L. Schneider, Steven C. Wilhelms, and Laurin I. Yates

Coastal and Hydraulics Laboratory

U.S. Army Engineer Research and Development Center

3909 Halls Ferry Road

Vicksburg, MS 39180-6199

Final report

Approved for public release; distribution is unlimited 


\begin{abstract}
SELECT is a numerical, one-dimensional model of selective withdrawal developed at the U.S. Army Engineer Research and Development Center. SELECT v1.0 Beta uses Microsoft Excel spreadsheet software to compute withdrawal characteristics and release water quality for various operational alternatives. The spreadsheet implementation of the SELECT model provides a highly interactive environment for the application of the model. This guide was developed to assist users of the SELECT v1.0 Beta spreadsheet model. The guide briefly discusses the concepts of selective withdrawal in reservoirs and describes how those concepts are implemented in the spreadsheet model. It then provides an overview of the execution of the spreadsheet model and includes guidance on preparing the required input data for the model. Examples of model input and model output are provided.
\end{abstract}

DISCLAIMER: The contents of this report are not to be used for advertising, publication, or promotional purposes. Citation of trade names does not constitute an official endorsement or approval of the use of such commercial products. All product names and trademarks cited are the property of their respective owners. The findings of this report are not to be construed as an official Department of the Army position unless so designated by other authorized documents.

DESTROY THIS REPORT WHEN IT IS NO LONGER NEEDED. DO NOT RETURN TO THE ORIGINATOR. 


\section{Contents}

Conversion Factors, Non-SI to SI Units of Measurement................................. iv

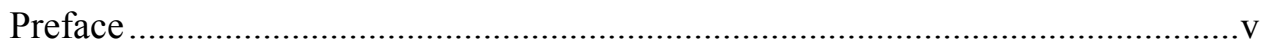

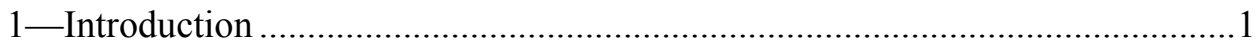

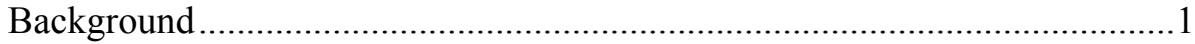

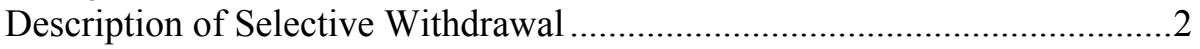

Implementation of Selective Withdrawal ................................................... 3

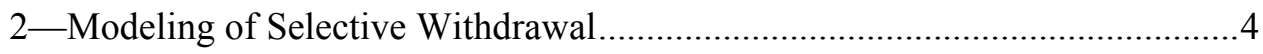

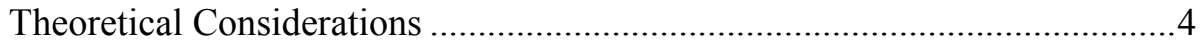

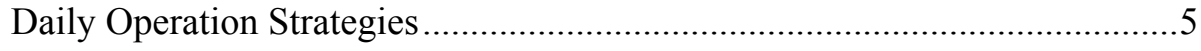

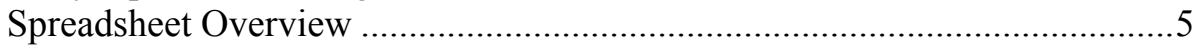

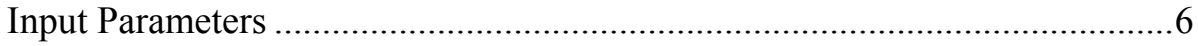

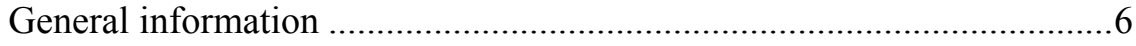

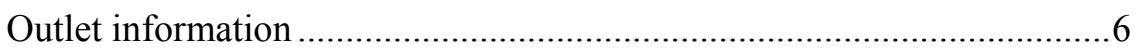

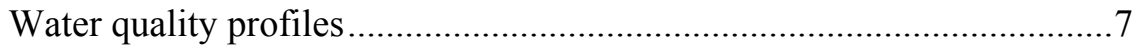

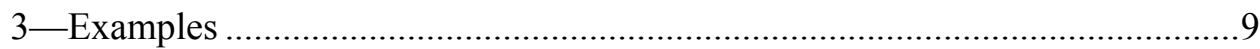

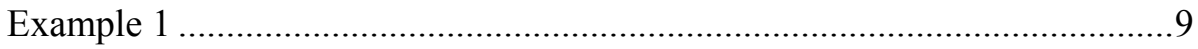

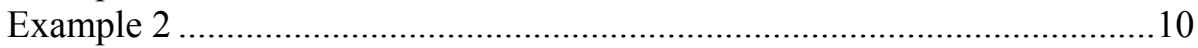

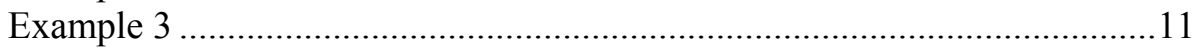

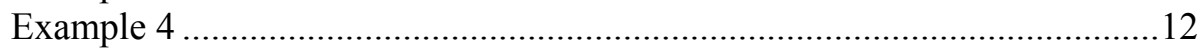

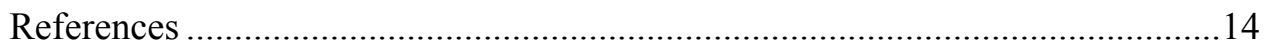

SF 298 


\section{Conversion Factors, Non-SI to SI Units of Measurement}

Non-SI units of measurement used in this report can be converted to SI units as follows:

\begin{tabular}{|l|l|l||}
\hline Multiply & By & To Obtain \\
\hline \hline Cubic feet & 0.02831685 & Cubic meters \\
\hline Degrees (angle) & 0.01745329 & Radians \\
\hline Feet & 0.3048 & Meters \\
\hline
\end{tabular}




\section{Preface}

The work reported herein was conducted as part of the Water Operations Technical Support (WOTS) Program. The WOTS Program is sponsored by Headquarters, U.S. Army Corps of Engineers (HQUSACE), and is assigned to the U.S. Army Engineer Research and Development Center (ERDC) under the purview of the Environmental Laboratory (EL), Vicksburg, MS. Funding was provided under Department of the Army Appropriation 96X3123, Operations and Maintenance. Mr. Robert C. Gunkel, Jr., was Program Manager for the WOTS Program. Program Monitor during this study was Mr. James Crum, HQUSACE.

This guide was prepared by Mr. Michael L. Schneider, Dr. Steven C. Wilhelms, and Ms. Laurin I. Yates of the Inland Hydraulic Structures Branch, Coastal and Hydraulics Laboratory (CHL), Vicksburg, MS.

Mr. Charles H. Tate, Jr., Chief of the Inland Hydraulic Structures Branch directed the study and helped coordinate the effort under the general supervision of Mr. Thomas W. Richardson, Director, CHL.

COL James R. Rowan, EN, was Commander and Executive Director of ERDC. Dr. James R. Houston was Director. 


\section{Introduction}

\section{Background}

The U.S. Army Corps of Engineers has been using selective withdrawal to manage reservoir water quality since 1973 . Selective withdrawal refers to a method of withdrawing water from an impoundment in a region restricted vertically by the ambient stratification. Typically, selective withdrawal operations are determined by trying to meet established downstream water quality goals (in most cases temperature). Meeting a daily release-quality target involves selecting an outlet or outlets for which the flow-weighted release quality approaches the objective. If multiple water quality objectives are to be considered, the decision-making strategy becomes much more complex. The relative importance of deviating from the release objectives for all the important water quality parameters must be considered. Additionally, an operational strategy that considers only the immediate consequences of a release neglects the future availability of water quality resources. Effective management of reservoir water quality for controlling release quality requires an understanding of the relationship between project withdrawals and reservoir limnology.

A question frequently faced by water control managers is, "What will be the release water quality corresponding to a given operating condition?" If a multilevel selective withdrawal tower is present, the question then becomes, "What outlets should be operated to achieve target release water quality objectives?" A numerical model of project withdrawals entitled SELECT (Davis et al. 1987) was developed to help address these questions. This FORTRAN program estimates release water quality as a function of the outlet geometry, discharge, and in-lake water quality profiles.

The spreadsheet version of SELECT SELECT Version 1.0 Beta, can be accessed through standard Microsoft Excel 2000 software. Porting the calculational procedures into a spreadsheet provides a highly interactive environment. This environment provides for easy data entry and analysis of model results. A wide range of operational alternatives can be screened in this new release of SELECT in a fraction of the time required by past releases. The objective of this report is to provide a user's guide for the use and application of SELECT Version 1.0 Beta. 


\section{Description of Selective Withdrawal}

Selective withdrawal capabilities often can provide the operational flexibility to respond to water quality demands both in-reservoir and downstream. The hydrodynamics associated with reservoir releases provide an important linkage between water quality and reservoir management strategy. When an outflow is initiated, the resultant velocity field is independent of the density characteristics in the impoundment. The zone of withdrawal at this point encompasses the entire depth of the impoundment. The withdrawal zone is quickly restricted in an upstream direction by density stratification. The flow field develops with a jetlike velocity distribution. Regions in the impoundment above and below the newly established withdrawal limits do not contribute to project releases. The velocity field upstream of the outlet quickly approaches steady conditions within minutes of the initiation of discharge. This type of flow field has been called selective withdrawal since most of the flow is withdrawn near the level of the outlet.

Quantifying the flow characteristics to an outlet depends upon the discharge, stratification, geometry of the outlet, bathymetry of the impoundment, and any in-reservoir circulation. Any variation of these properties may lead to significant changes to the flow field and to the release water quality. The outlets in reservoirs have traditionally been classified as either point or line sinks. Typically, the portals in a selective withdrawal tower can be characterized as a point sink while spillways approximate line sinks. The characteristics of outflows to both line and point sinks subject to quasi-linear stratification are governed by the densimetric Froude number (Bohan and Grace 1973). The relationship for a point sink states that the half-thickness of the withdrawal zone is a function of the ratio of the flow rate to the buoyancy frequency of the fluid raised to the onethird power. The corresponding relationship for a line sink equates the halfthickness of the withdrawal zone to the square root of the unit discharge divided by the buoyancy frequency (Imberger and Patterson 1990). The vertical extent of the withdrawal zone is directly proportional to the cube root of discharge. In general, the extent of the withdrawal zone will not vary greatly in response to changes in discharge. An eightfold increase in discharge to a point sink will double the extent of the withdrawal zone, assuming no boundary interference.

A weak inverse relationship exists between the strength of stratification and the extent of the withdrawal zone. The presence of a large density gradient can act as a barrier to the extent of the withdrawal zone. The potential energy contained in regions of high-density gradient can exceed the available kinetic energy resulting in a truncated velocity profile at the density interface. On the other hand, regions with little or no density gradient provide little resistance to the developing withdrawal zone, resulting in a nearly uniform velocity profile.

The withdrawal zone will generally be hydrodynamically established within one withdrawal zone thickness of the outlet upstream into the reservoir. If physical obstructions like the reservoir floor, the banks of an excavated approach channel, or a canyon wall are present near the outlet, the development of the withdrawal zone may be affected. Smith et al. (1987) introduced the concept of the withdrawal angle to account for these obstructions. The withdrawal zone can 
be further modified by far-field topographic influences such as cofferdams, broad crested weirs, and natural obstructions. In many circumstances, it is these features that shape the withdrawal of water from the main body of the reservoir.

Other processes that contribute to reservoir circulation and mixing have the potential to influence the withdrawal current structure. The influence of internal seiching motion has the potential to significantly change the vertical density structure in a reservoir, resulting in large changes in release water quality. The strong currents resulting from inflow and wind events not only can change the density structure in an impoundment in a relatively short time, but can interact with a release current to effectively change the composite velocity distribution.

\section{Implementation of Selective Withdrawal}

The technique of selective withdrawal has been used for years to control the quality of water released from a stratified body of water. It is estimated that there are more than 70 reservoirs with designed selective withdrawal capability in the U.S. Army Corps of Engineers (CE) system. Selective withdrawal structures are generally located in the deepest portion of a reservoir near the dam. Most selective withdrawal structures are constructed as face-of-the-dam intakes that are an integral part of the vertical upstream face of a concrete dam, as inclined intakes on a sloping embankment of an earthen and rock-fill dam, or as a freestanding tower immediately upstream of the dam. Releases from multiple vertical levels have generally been accomplished by employing a dual wet well system. Water is withdrawn from the desired levels in the pool from each wet well with the combined flows mixed in the turbulent flow downstream from the projects. In some instances, the discharge through each wet well is controlled by a separate flow control. Separate flow control for each of the levels of withdrawal is not always possible. For example, the addition of hydropower to a selective withdrawal structure often shifts the flow control downstream to the turbines, which places all the ports upstream of a single control point. The flow rates from each level of open ports in the stratified pool are not prescribed in the singleflow-control blending mode. A procedure to estimate the flow distribution between outlets in a single wet well has been developed by Howington (1990).

Dams without designed selective withdrawal outlet structures may still release water from alternative elevations through regulating outlets, sluiceways, fish bypass conduits, low flow water quality conduits, or spillways. Selective withdrawal capabilities may be added to an existing dam through several techniques. A structural enclosure enabling selective withdrawal of water to an outlet has been added to the face of the dam on several occasions. Various modifications to trashracks and bulkhead slots have been conducted to alter the level of withdrawal for the enhancement of release water quality (Price 1990). Skimming weirs have also been used to modify releases from stratified impoundments. 


\section{Modeling of Selective Withdrawal}

\section{Theoretical Considerations}

A means of predicting the properties of selective withdrawal is helpful to properly design and efficiently operate a selective withdrawal facility. Significant research has been conducted on the characteristics of withdrawal from a stratified impoundment. The result of this work within the $\mathrm{CE}$ is a numerical model entitled SELECT, which is a one-dimensional, steady-state model of withdrawal from a stratified impoundment. SELECT Version 1.0 Beta has been designed to reproduce the calculational procedure used by SELECT. It computes the vertical distribution of withdrawal for an outlet port based upon a user-specified density profile (usually input as temperature). The limits of withdrawal are determined from empirically developed scaling relationships (Froude number) for point and line sinks. The discharge, outlet port geometry, and strength of stratification are required to estimate the limits of withdrawal.

The computational procedures used in this spreadsheet have been taken primarily from the work of Bohan and Grace (1973) and Smith et al. (1987). The location of the withdrawal limits is determined by applying an empirically derived densimetric Froude number relationship. The Froude number relationship for outlet ports (point sink) is as

$$
d=C\left(\frac{Q}{N}\right)^{1 / 3}
$$

where

$d=$ half-thickness of the withdrawal zone, $\mathrm{ft}$ or $\mathrm{m}$

$C=$ proportionality coefficient

$Q=$ total flow rate per radial angle, $\mathrm{cu} \mathrm{ft} / \mathrm{sec}$ or $\mathrm{cu} \mathrm{m} / \mathrm{sec}$

$N=$ Brunt-Vaisala frequency, $\mathrm{L} / \mathrm{sec}$

and

$$
N=\left(\partial \rho * g / d z / \rho^{\prime}\right)^{1 / 2}
$$


where

$$
\begin{aligned}
\partial & =\text { gradient operator } \\
\rho & =\text { density, } \mathrm{g} / \mathrm{m}^{3} \\
g & =\text { acceleration of gravity, } \mathrm{ft} / \mathrm{sec}^{2} \text { or } \mathrm{m} / \mathrm{sec}^{2} \\
z & =\text { vertical dimension, } \mathrm{m} \text { or } \mathrm{ft} \\
\rho^{\prime} & =\text { reference density, } \mathrm{g} / \mathrm{m}^{3}
\end{aligned}
$$

A shape function based upon the variation of potential energy about the outlet is then applied to determine the velocity distribution. Based upon this withdrawal distribution, SELECT will also compute release water quality when given the vertical distribution of the quality parameter of interest. A flowweighted average is applied to calculate the release water quality, which is treated conservatively. The input data required to run this spreadsheet include reservoir water quality profiles, outlet port geometry and capacity, and proposed outlet discharge.

\section{Daily Operation Strategies}

A problem faced by reservoir managers is the daily or short-term operation of a selective withdrawal structure to provide release water quality that meets specific management objectives. The operational decision will identify which ports to open as well as the associated distribution of flow between them. This decision will depend upon the release water quality objectives at the project, water quality conditions in the reservoir, total discharge, and hydraulic constraints of the outlet structure. Typically, the primary water quality objectives stem from goals to provide water resources for wildlife maintenance, water supply, and recreation. Alternative objectives may include the release of water for the enhancement of in-reservoir water quality. The short-circuiting of a turbid inflow for passage downstream is an example of this type of operational objective. The resource manager is generally provided with the release water quality objectives throughout the period of interest and the required daily discharge. The selection of outlet structure operation subject to a single water quality objective generally is a tractable problem. However, when multiple water quality objectives are identified, the appropriate operation may not be easily identified, requiring a more sophisticated decision-support model (Fontane et al. 1982) to aid the reservoir manager in choosing an operational strategy for a selective withdrawal structure.

\section{Spreadsheet Overview}

SELECT is intended to provide the user with an estimate of the release water quality from a stratified impoundment through a structure with intake ports. The

user must supply the spreadsheet model with in-lake water quality profiles, outlet port elevation, and discharge.

To properly use this spreadsheet model, the user must first enter the appropriate project-specific information in the highlighted cells on the input worksheet. The user must supply the following information: 
a. Water surface and impoundment bottom elevations.

b. Outlet port elevation, discharge, and withdrawal angle.

c. Water quality profile(s).

Once these data have been entered, the spreadsheet automatically updates the estimates of release water quality. The results from these operations can be viewed in a tabulated or graphical form. The current version of this spreadsheet accommodates temperature and up to four other water quality constituents. The first water quality profile must be temperature in degrees centigrade.

\section{Input Parameters}

This is the gateway to three areas of user-supplied input data: general information, outlet information, and water quality profiles.

\section{General information}

The following general data are required as user input:

a. Title - User-defined text describing current application (limited to 30 or fewer characters).

b. Day - The day of the month (1-31) for the input profile.

c. Month - The month for the input profile (1-12).

d. Year - The year for the input profile, four digits (2003).

e. WSE - The water surface elevation of the lake in user-selected units (non-SI or SI).

f. LBE - The lake bottom elevation in consistent units.

g. Gravity - (acceleration of gravity: $32.2 \mathrm{ft} / \mathrm{sec}^{2}$ for non-SI or $9.81 \mathrm{~m} / \mathrm{sec}^{2}$ for SI). Gravity units determine units for discharge and elevation. ${ }^{1}$

\section{Outlet information}

Port elevation. Enter the port center-line elevation for up to five outlets. These elevations can be entered in any order with multiple ports located at the same elevation. For outlets with a large vertical extent such as a bell mouth entrance, use the center line of the outlet at the face of the dam or structure. The

\footnotetext{
${ }^{1}$ A table of factors for converting non-SI units of measurement to SI units is presented on page iv.
} 
release qualities for multiple ports operated at a single elevation will differ slightly from withdrawing the same total discharge through a single port.

Port flow. Enter the corresponding flow rate for ports 1-5. The units of the discharge must be consistent with the selected units ( $\mathrm{cfs}$ or $\mathrm{cms}$ ). If more than one level of ports is operated in a single wet well tower, then the distribution of flow through each level becomes more difficult to determine (Howington 1989).

Port withdrawal angle. Enter the withdrawal angle, specified in degrees (0-360). The withdrawal angle reflects the plan view interference of solid boundaries (i.e., dam, piers, abutments, embankments, etc.). The approach flow to an outlet conceptualized as a point sink can be approximated as radial flow with the withdrawal angle representing the plan view geometric nature of this flow. A standpipe withdrawing water unobstructed from an impoundment would have a withdrawal angle of 360 degrees. An outlet located in the face of the dam would have flow approaching from only 180 degrees. For most outlet towers a withdrawal angle of 180 degrees is appropriate because of the obstruction caused by the face of the tower (Smith et al. 1987).

Note: In SELECT Version 1.0 Beta, the outlet must be conceptualized as a port (point sink). Other outlets, such as weirs or line sinks, have not been included in the computational algorithms. The specification of an outlet as a port is generally appropriate for water quality outlets, sluiceways, floodgates, bypass outlets, and hydropower discharges from single units. A general rule of thumb pertaining to the classification of the outlet type involves determining the ratio of outlet width to height. If the ratio of outlet width to height is greater than five, then the point sink conceptualization has been violated. Predicted withdrawal and release characteristics are like in error.

\section{Water quality profiles}

The user is allowed to enter water quality profiles manually. If the data exist in an ASCII file outside the spreadsheet, it can be imported for use with this model. The user will find the active cells located in the data entry section for water quality profiles. The data must be entered with increasing depth with a maximum of 50 entries and a minimum of 2 entries. The units of depth (non-SI or SI) must be consistent with other input data.

The second column must contain the corresponding temperatures in degrees centigrade at each of the sampled depths. The temperature is required to determine the corresponding density at each depth. The density is solely a function of temperature in this version of the spreadsheet model.

Up to four additional water quality constituents can be entered in this data section. The label for each column of data can be entered by the user. A corresponding value of each water quality constituent must be entered for each depth entry. An "empty cell" will be treated as a zero value and will be reflected in release water quality estimates. A constant value for each water quality constituent is assumed above and below the highest and lowest observation. The 
value of water quality parameters is assumed to vary linearly between observations.

When the general information, outlet information, and water quality profiles have been entered, the spreadsheet automatically calculates the results. These can be found on the Output Worksheet in the spreadsheet. The General Information that was entered on the Input Data worksheet is repeated on the Output Worksheet, including the Title, Date, Outlet and Operations Information. Just below this, in the section Release Water Quality, are the results of the input data. All of the General Information and Release Water Quality results are repeated in the section entitled Comparison Summary. Included in the Comparison Summary section is space to retain Current Alternative computations. To retain current alternative computations, the user needs to copy information from the Current Alternative rows in the Comparison Summary section and paste into the Comparison Summary table as values. 


\section{Examples}

The following examples are provided to illustrate the operation of this spreadsheet model. These examples can also be used to test the proper operation of the spreadsheet.

- Example 1 - Single-port operation.

- Example 2-Single-port operation.

- Example 3 - Dual-port operation to meet temperature objective.

- Example 4 - Four-port operation with temperature profile only.

\section{Example 1}

Upper port withdrawal of $500 \mathrm{cfs}$ (note non-SI units chosen). The water quality profiles are defined at four depth stations.

- General Information - 30-Apr-03 Lake John Doe

- $\quad$ Title - Lake John Doe (Title of simulation, less than 30 characters)

- Day - 30 (Day, 1-31)

- Month - 4 (Month, 1-12)

- $\quad$ Year - 2003 (Year, four digits)

- WSE - 200.00 (Water Surface Elevation)

- $\quad$ LBE - 0.00 (Lake Bottom Elevation)

- Gravity - 32.20 (non-SI 32.2 or SI 9.81, with 32.2 discharge and elevation units set as non-SI) 


\begin{tabular}{||l|l|l|l||}
\hline \hline \multicolumn{4}{|l|}{ Outlet Information } \\
\hline \hline Port & Elevation, ft & Flow, cu ft/sec & W-Angle, deg \\
\hline \hline 1 & 180.00 & 500.00 & 180.00 \\
\hline 2 & 150.00 & 0.00 & 180.00 \\
\hline 3 & 120.00 & 0.00 & 180.00 \\
\hline 4 & 80.00 & 0.00 & 180.00 \\
\hline 5 & 10.00 & 0.00 & 180.00 \\
\hline
\end{tabular}

\begin{tabular}{|l|l|l|l|l|l||}
\hline \multicolumn{6}{||l||}{ Release Water Quality } \\
\hline \hline $\begin{array}{l}\text { Density, } \\
\text { g/cu cm }\end{array}$ & $\begin{array}{l}\text { Temp } \\
\left({ }^{\circ} \mathrm{C}\right)\end{array}$ & $\begin{array}{l}\text { DO, } \\
\mathbf{m g} / \mathbf{l}\end{array}$ & $\begin{array}{l}\text { Conductivity, } \\
\boldsymbol{\mu m h o s}\end{array}$ & $\begin{array}{l}\text { Phosphorus, } \\
\mathbf{m g} / \mathbf{l}\end{array}$ \\
\hline \hline 0.99725 & 24.03 & 6.51 & 28.01 & 6.74 & 12.75 \\
\hline \hline
\end{tabular}

\begin{tabular}{|c|c|c|c|c|c|c|}
\hline \multicolumn{7}{|c|}{ Water Quality Profiles } \\
\hline Entry & Depth, $\mathrm{ft}$ & Temp, ${ }^{\circ} \mathrm{C}$ & $\mathrm{DO}, \mathrm{mg} / \mathrm{l}$ & $\begin{array}{l}\text { Conductivity, } \\
\mu \mathrm{mhos}\end{array}$ & $\mathrm{pH}$ & Phosphorus, mg/ \\
\hline 1 & 0.00 & 29.00 & 7.90 & 28.00 & 6.70 & 8.00 \\
\hline 2 & 30.00 & 28.00 & 7.90 & 28.00 & 6.70 & 12.00 \\
\hline 3 & 60.00 & 18.00 & 4.50 & 28.00 & 6.80 & 15.00 \\
\hline 4 & 200.00 & 16.00 & 3.20 & 35.00 & 6.70 & 18.00 \\
\hline
\end{tabular}

\section{Example 2}

Port 2 withdrawal of $500 \mathrm{cfs}$ (note non-SI units chosen). The water quality profiles have not changed from the first example.

- General Information - 30-Apr-03 Lake John Doe

- $\quad$ Title - Lake John Doe (Title of simulation, less than 30 characters)

- Day - 30 (Day, 1-31)

- Month - 4 (Month, 1-12)

- Year - 2003 (Year, four digits)

- WSE - 200.00 (Water Surface Elevation)

- $\quad$ LBE - 0.00 (Lake Bottom Elevation)

- Gravity - 32.20 (non-SI 32.2 or SI 9.81, with 32.2 discharge and elevation units set as non-SI) 


\begin{tabular}{||l|l|l|l||}
\hline \hline \multicolumn{4}{|l|}{ Outlet Information } \\
\hline \hline Port & Elevation, ft & Flow, cu ft/sec & W-Angle, deg \\
\hline \hline 1 & 180.00 & 0.00 & 180.00 \\
\hline 2 & 150.00 & 500.00 & 180.00 \\
\hline 3 & 120.00 & 0.00 & 180.00 \\
\hline 4 & 80.00 & 0.00 & 180.00 \\
\hline 5 & 10.00 & 0.00 & 180.00 \\
\hline
\end{tabular}

\begin{tabular}{||l|l|l|l|l|l||}
\hline \multicolumn{6}{||l||}{ Release Water Quality } \\
\hline \hline Density, g/cu m & Temp $\left({ }^{\circ} \mathrm{C}\right)$ & DO, mg/l & Conductivity, $\boldsymbol{\mu m h o s}$ & $\mathbf{p H}$ & Phosphorus, $\mathbf{m g} / \mathbf{l}$ \\
\hline \hline 0.99785 & 21.65 & 5.74 & 28.02 & 6.76 & 13.91 \\
\hline \hline
\end{tabular}

\begin{tabular}{|c|c|c|c|c|c|c|}
\hline \multicolumn{7}{|c|}{ Water Quality Profiles } \\
\hline Entry & Depth, $\mathrm{ft}$ & Temp, ${ }^{\circ} \mathrm{C}$ & $\mathrm{DO}, \mathrm{mg} / \mathrm{l}$ & $\begin{array}{l}\text { Conductivity, } \\
\mu \mathrm{mhos}\end{array}$ & $\mathrm{pH}$ & Phosphorus, mg/l \\
\hline 1 & 0.00 & 29.00 & 7.90 & 28.00 & 6.70 & 8.00 \\
\hline 2 & 30.00 & 28.00 & 7.90 & 28.00 & 6.70 & 12.00 \\
\hline 3 & 60.00 & 18.00 & 4.50 & 28.00 & 6.80 & 15.00 \\
\hline 4 & 200.00 & 16.00 & 3.20 & 35.00 & 6.70 & 18.00 \\
\hline
\end{tabular}

\section{Example 3}

Information from Examples 1 and 2 can be used to approximate operating conditions resulting in a release target temperature of $24^{\circ} \mathrm{C}$. To release the target temperature of $24^{\circ} \mathrm{C}$, the flow through each port can be approximated based on a mass and temperature balance.

$$
\begin{aligned}
& Q_{\text {total }}=Q_{180}+Q_{150} \\
& Q_{\text {total }} * T_{o b j}=Q_{180} * T_{180}+Q_{150} * T_{150}
\end{aligned}
$$

Substituting the following values into these equations, $Q_{\text {total }}$ is $500 \mathrm{cfs}, T_{o b j}$ is $24^{\circ} \mathrm{C}, T_{180}$ is $28.0^{\circ} \mathrm{C}$, and $T_{150}$ is $21.8^{\circ} \mathrm{C}$, gives $Q_{180}=182.0 \mathrm{cfs}$ and $Q_{150}=$ $318.0 \mathrm{cfs}$.

Enter these values in the outlet information table as flows for ports 1 and 2. Note the release water temperature of 24.03 is very near the target release water temperature of 24.00 . The same general procedure can be repeated for other water quality objectives.

- General Information - 30-Apr-03 Lake John Doe 
- Title - Lake John Doe (Title of simulation, less than 30 characters)

- Day - 30 (Day, 1-31)

- Month -4 (Month, 1-12)

- Year - 2003 (Year, four digits)

- WSE - 200.00 (Water Surface Elevation)

- $\mathbf{L B E}-0.00$ (Lake Bottom Elevation)

- Gravity - 32.20 (non-SI 32.2 or SI 9.81, with 32.2 discharge and elevation units set as non-SI)

\begin{tabular}{||l|l|l|l||}
\hline \multicolumn{4}{||}{ Outlet Information } \\
\hline \hline Port & Elevation, ft & Flow, cu ft/sec & W-Angle, deg \\
\hline \hline 1 & 180.00 & 182.00 & 180.00 \\
\hline 2 & 150.00 & 318.00 & 180.00 \\
\hline 3 & 120.00 & 0.00 & 180.00 \\
\hline 4 & 80.00 & 0.00 & 180.00 \\
\hline 5 & 10.00 & 0.00 & 180.00 \\
\hline \hline
\end{tabular}

\begin{tabular}{|c|c|c|c|c|c|}
\hline \multicolumn{6}{|c|}{ Release Water Quality } \\
\hline $\begin{array}{l}\text { Density, g/cu } \\
\mathrm{cm}\end{array}$ & $\begin{array}{l}\text { Temp } \\
\left({ }^{\circ} \mathrm{C}\right)\end{array}$ & $\begin{array}{l}\text { DO, } \\
\mathrm{mg} / \mathrm{l}\end{array}$ & $\begin{array}{l}\text { Conductivity, } \\
\mu \text { mhos }\end{array}$ & $\mathrm{pH}$ & $\begin{array}{l}\text { Phosphorus, } \\
\mathrm{mg} / \mathrm{l}\end{array}$ \\
\hline 0.99725 & 24.03 & 6.51 & 28.01 & 6.74 & 12.75 \\
\hline
\end{tabular}

\begin{tabular}{|c|c|c|c|c|c|c|}
\hline \multicolumn{7}{|c|}{ Water Quality Profiles } \\
\hline Entry & Depth, ft & Temp, ${ }^{\circ} \mathrm{C}$ & DO, mg/l & $\begin{array}{l}\text { Conductivity, } \\
\mu \text { mhos }\end{array}$ & $\mathrm{pH}$ & Phosphorus, mg/l \\
\hline 1 & 0.00 & 29.00 & 7.90 & 28.00 & 6.70 & 8.00 \\
\hline 2 & 30.00 & 28.00 & 7.90 & 28.00 & 6.70 & 12.00 \\
\hline 3 & 60.00 & 18.00 & 4.50 & 28.00 & 6.80 & 15.00 \\
\hline 4 & 200.00 & 16.00 & 3.20 & 35.00 & 6.70 & 18.00 \\
\hline
\end{tabular}

\section{Example 4}

The flow is taken from four separate levels. Note: only temperature was entered in the water quality profile section.

- General Information - 30-Apr-03 Lake John Doe

- $\quad$ Title - Lake John Doe (Title of simulation, less than 30 characters) 
- Day - 30 (Day, 1-31)

- Month - 4 (Month, 1-12)

- Year - 2003 (Year, four digits)

- WSE - 200.00 (Water Surface Elevation)

- $\quad$ LBE - 0.00 (Lake Bottom Elevation)

- Gravity -32.20 (non-SI 32.2 or SI 9.81, with 32.2 discharge and elevation units set as non-SI)

\section{Outlet Information}

\begin{tabular}{||l|l|l|l||}
\hline \hline Port & Elevation, ft & Flow, cu ft/sec & W-Angle, deg \\
\hline \hline 1 & 180.00 & 250.00 & 180.00 \\
\hline 2 & 150.00 & 50.00 & 180.00 \\
\hline 3 & 120.00 & 100.00 & 180.00 \\
\hline 4 & 80.00 & 100.00 & 180.00 \\
\hline 5 & 10.00 & 0.00 & 180.00 \\
\hline
\end{tabular}

\begin{tabular}{|l|l|l|l|l|l||}
\hline \hline \multicolumn{6}{||l|}{ Release Water Quality } \\
\hline \hline $\begin{array}{l}\text { Density, g/cu } \\
\text { cm }\end{array}$ & $\begin{array}{l}\text { Temp } \\
\left.{ }^{\circ} \mathrm{C}\right)\end{array}$ & $\begin{array}{l}\text { DO, } \\
\mathbf{m g} / \mathbf{l}\end{array}$ & $\begin{array}{l}\text { Conductivity, } \\
\boldsymbol{\mu m h o s}\end{array}$ & $\begin{array}{l}\text { Phosphorus, } \\
\mathbf{m g} / \mathrm{l}\end{array}$ \\
\hline \hline 0.99739 & 23.22 & 0.00 & 0.00 & 0.00 & 0.00 \\
\hline \hline
\end{tabular}

\begin{tabular}{|c|c|c|c|c|c|c|}
\hline \multicolumn{7}{|c|}{ Water Quality Profiles } \\
\hline Entry & Depth, ft & Temp, ${ }^{\circ} \mathrm{C}$ & Do, mg/l & $\begin{array}{l}\begin{array}{l}\text { Conductivity, } \\
\mu \text { mhos }\end{array} \\
\end{array}$ & $\mathrm{pH}$ & Phosphorus, mg/l \\
\hline 1 & 0.00 & 29.00 & & & & \\
\hline 2 & 30.00 & 28.00 & & & & \\
\hline 3 & 60.00 & 18.00 & & & & \\
\hline 4 & 200.00 & 16.00 & & & & \\
\hline
\end{tabular}




\section{References}

Bohan, J. P., and Grace, J. L., Jr. (1973). "Selective withdrawal from man-made lakes; Hydraulic laboratory investigation," Technical Report H-73-4, U.S. Army Engineer Waterways Experiment Station, Vicksburg, MS.

Davis, J. E., Holland, J. P., Schneider, M. L., and Wilhelms, S. C. (1987). "SELECT: A numerical one-dimensional model for selective withdrawal," Instruction Report E-87-2, U.S. Army Engineer Waterways Experiment Station, Vicksburg, MS.

Fontane, D. G., Labadie, J. W., and Loftis, B. (1982). "Optimal control of reservoir discharge quality through selective withdrawal," Technical Report E-82-1, Colorado State University and the U.S. Army Engineer Waterways Experiment Station, Vicksburg, MS.

Howington, S. E. (1989). "Intake structure operation study, Lost Creek Dam, Oregon," Technical Report, HL-89-13, U.S. Army Engineer Waterways Experiment Station, Vicksburg, MS.

. (1990). "Simultaneous, multiple-level withdrawal from a density stratified reservoir," Technical Report W-90-1, U.S. Army Engineer Waterways Experiment Station, Vicksburg, MS.

Imberger, J., and Patterson, J. C. (1990). "Physical limnology," Advances in Applied Mechanics 27, 303-475.

Price, R. E. (1990). "Water quality enhancement techniques used within the Corps of Engineers," Miscellaneous Paper W-90-1, U.S. Army Engineer Waterways Experiment Station, Vicksburg, MS.

Smith, D. R., Wilhelms, S. C., Holland, J. P., Dortch, M. S., and Davis, J. E. (1987). "Improved description of selective withdrawal through point sinks," Technical Report E-87-2, U.S. Army Engineer Waterways Experiment Station, Vicksburg, MS. 


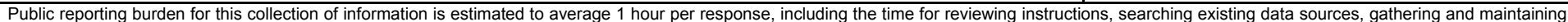

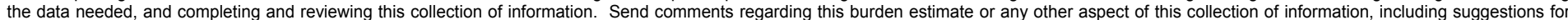

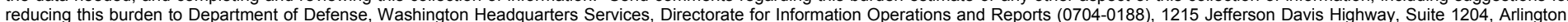

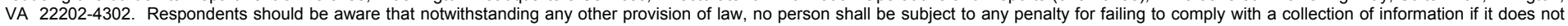
display a currently valid OMB control number. PLEASE DO NOT RETURN YOUR FORM TO THE ABOVE ADDRESS.
1. REPORT DATE (DD-MM-YYYY)
February 2004

\section{TITLE AND SUBTITLE}

SELECT Version 1.0 Beta: A One-Dimensional Reservoir Selective Withdrawal Model Spreadsheet

\section{DATES COVERED (From - To)}

5a. CONTRACT NUMBER

5b. GRANT NUMBER

5c. PROGRAM ELEMENT NUMBER

5d. PROJECT NUMBER

5e. TASK NUMBER

5f. WORK UNIT NUMBER

8. PERFORMING ORGANIZATION REPORT NUMBER

ERDC/EL SR-04-1

U.S. Army Engineer Research and Development Center

Coastal and Hydraulics Laboratory

3909 Halls Ferry Road, Vicksburg, MS 39180-6199

\section{SPONSORING / MONITORING AGENCY NAME(S) AND ADDRESS(ES)}

10. SPONSOR/MONITOR'S ACRONYM(S)

U.S. Army Corps of Engineers

Washington, DC 20314-1000

11. SPONSOR/MONITOR'S REPORT NUMBER(S)

\section{DISTRIBUTION / AVAILABILITY STATEMENT}

Approved for public release; distribution is unlimited.

\section{SUPPLEMENTARY NOTES}

\section{ABSTRACT}

SELECT is a numerical, one-dimensional model of selective withdrawal developed at the U.S. Army Engineer Research and Development Center. SELECT v1.0 Beta uses Microsoft Excel spreadsheet software to compute withdrawal characteristics and release water quality for various operational alternatives. The spreadsheet implementation of the SELECT model provides a highly interactive environment for the application of the model. This guide was developed to assist users of the SELECT v1.0 Beta spreadsheet model. The guide briefly discusses the concepts of selective withdrawal in reservoirs and describes how those concepts are implemented in the spreadsheet model. It then provides an overview of the execution of the spreadsheet model and includes guidance on preparing the required input data for the model. Examples of model input and model output are provided.

\section{SUBJECT TERMS}

Outlet structures

Reservoirs

16. SECURITY CLASSIFICATION OF:

\begin{tabular}{|l|l|}
\hline a. REPORT & b. ABSTRACT \\
UNCLASSIFIED & UNCLASSIFIED \\
\hline
\end{tabular}

Selective withdrawal

Stratification

Stratified flow

c. THIS PAGE
UNCLASSIFIED

\begin{tabular}{l|c|}
$\begin{array}{l}\text { 17. LIMITATION } \\
\text { OF ABSTRACT }\end{array}$ & $\begin{array}{c}\text { 18. NUMBER } \\
\text { OF PAGES }\end{array}$ \\
& 00
\end{tabular}

Water quality

19a. NAME OF RESPONSIBLE PERSON

19b. TELEPHONE NUMBER (include area code) 